\author{
Review Article
}

\title{
ROLE OF AGNIKARMA IN PAIN MANAGEMENT OF VARIOUS MUSCULOSKELETAL DISORDERS: A REVIEW STUDY
}

\section{Badwe Yogesh', Shilvant Rishabh ${ }^{2 *}$, Shinde Jyoti ${ }^{3}$}

1Professor and HOD, *2PG Scholar, ${ }^{3}$ Professor, Department of Shalyatantra, Shri Ayurved Mahavidyalaya, Nagpur, Maharashtra, India.

\begin{tabular}{|c|c|}
\hline Artic & \multirow{8}{*}{$\begin{array}{l}\text { ABSTRACT } \\
\text { Agnikarma is one of the important Para-surgical procedures described in Ayurveda, which has } \\
\text { been widely used in the clinical practice now days. Sushruta has given detail description about } \\
\text { Agnikarma. Superiority of Agnikarma over other the treatment modalities are timely described } \\
\text { by our ancienter because of its Apunrabhavatva i.e., no recurrence property. Pain (Ruja) is the } \\
\text { cardinal feature of most of the musculoskeletal disorders and it can affect the quality of life. In } \\
\text { modern lifestyle, patient needs instant relief from pain. Treatment available in modern } \\
\text { medicine commonly NSAID's (Nonsteroidal anti-inflammatory drugs) but it has some hazardous } \\
\text { effects on body. This review is an attempt has been made to study various research article, } \\
\text { analyzed the role of Agnikarma and its applicability on various painful disorders which help to } \\
\text { gain best knowledge about Agnikarma. In this article total } 15 \text { research works from various } \\
\text { journals have been studied conducted on Agnikarma. Agnikarma was found very important tool } \\
\text { in pain management of many musculoskeletal disorders. It was found safe, easy, cost-effective } \\
\text { and OPD level procedure. }\end{array}$} \\
\hline story: & \\
\hline & \\
\hline & \\
\hline 30-08-2021 & \\
\hline & \\
\hline & \\
\hline & \\
\hline
\end{tabular}

\section{INTRODUCTION}

The word Agnikarma is combination of two words i.e., Agni and Karma, it means procedure done by the Agni to treat the disease. Application of heat directly or indirectly to the affected part of body. Sushruta mentioned the superiority of Agnikarma among all the para-surgical procedures and its importance explained in separate chapter in Sutrasthana. It has ability to cure the chronic diseases, which can't be cured by the Bheshaja (medicine), Shastra (Surgical interventions) and Ksharakarma (alkaline cauterization). It is mainly indicated in the disease caused by Vata and Kapha Doshas. Diseases of Twacha, Mamasa, Asthi \& Sandhi with severe pain caused due to vitiation of Vata. Also, in Shiro Roga, Netra Roga, Vartma Gata Vyadhi, Granthi, Arsha, Bhagandar, Arbuda, Shlipad, Charmakeela, Tila Kalaka, Antra Vrana, Nadi Vrana, and in the diseases of the joints.[1] According to Sushruta, if Agnikarma is performed in above diseases, will be less chances of recurrence and successful in curing the diseases. ${ }^{[2]}$

\begin{tabular}{|l|l|}
\hline \multicolumn{3}{|c|}{ Access this article online } \\
\hline Quick Response Code & \begin{tabular}{l} 
https://doi.org/10.47070/ijapr.v9i8.2040 \\
\hline
\end{tabular} \\
\cline { 2 - 2 }
\end{tabular}

Acharya Charak has not described details about Agnikarma but mentioned as one of the treatment measures in different Vatavyadhi such as Gridhrasi.[3] In Sushruta Samhita different Dahanopkarnas and shapes are mentioned for Agnikarma as follows; Twakadagdha - Pippali (Piper Longum), Aja Shakrut (goat excreta), Godanta (gypsum), Shara (arrow), Shalakha (metal rod) Mamsadagdha- Jambhavsta Shalakla and other metals. For Sira, Snayu, Sandhi and Asthi Dagdha - Kshaudra (honey), Guda (jaggery), and Sneha (oil).[4] Shape of Agnikarma: According to Sushruta, Valaya: (round shaped), Bindu: (dotted), Vilekha: (linear cauterization) and Pratisarana: (irregular shape) ${ }^{[5]}$ and according to Vagbhata three more types Ardha Chandra, Swastika and Astapada.

\section{OBJECTIVES}

1. To review the research work related to Agnikarma for pain management on different musculoskeletal disorders.

2. To analyze the collected data and study the efficacy of Agnikarma on pain management in various musculoskeletal disorders.

\section{MATERIALS AND METHODS}

The related data was collected from various dissertations, published research articles and from search engines like Google Scholar, PubMed and from the classical texts of Ayurveda. 


\section{OBSERVATION AND RESULT}

Dr Shrikant Patel has conducted RCT Agnikarma with two different Dahanupkarnas in Gridhrisi (Sciatica) as a PG dissertation. In this study total 30 patients were divided into two groups of two different Dahanupakarnas i.e., instruments Loha shalaka and Pippali. Follow up taken on $7^{\text {th }}$ and $14^{\text {th }}$ day and assessment was done immediately after the treatment. Results shown in Shalaka group mean score of pain which was BT-2.07 reduced to AT- 0.73, after first follow up reduced to 0.67 and last follow up was same with 64\%, 67.6\% and 67.6\% improvement respectively. Mean score of tenderness which was BT1.60 reduced to 0.47 with $70.6 \%$ improvement which was same after first and last follow up. there is marked improvement observed in 9 patients (60\%), moderate in 6 patients (40\%) and there are no patients with mild improvement was found. in Pippali group mean score of pain which was BT-1.93 reduced to 1.00 after treatment, after first and last follow up was same reduced to 0.87 with $48 \%, 55 \%$ and $51.8 \%$ improvement respectively. mean score of tenderness which was BT-1.93 reduced to 0.87 with $55 \%$ improvement after treatment which was same after first and last follow up, which is statistically significant ( $\mathrm{P} \leq 0.0001)$. There is marked improvement found in 4 patients (26.66\%), moderate in 9 patients $(60 \%)$ and mild improvement was observed in 2 patients (13. 33\%). So, conclusion made was Agnikarma with Loha Shalaka shows better result specially in reducing the pain than Pippali in all parameter in the Gridhrasi.[6]

Another RCT as a PG dissertation on Agnikarma with two different Shalaka's on osteoarthritis of knee joint conducted by Dr. Sucheta Ray. Total 30 patients were equally divided into two groups of Rajat Shalaka and Tamra Shalaka. Assessment was done after the follow up on $7^{\text {th }}$ and $14^{\text {th }}$ day. After completion of treatment, it was observed that, in Rajat Shalaka group mean score of pain was 1.87 before treatment which was reduced to 0.73 after treatment and 0.00 after last follow up with $100 \%$ improvement. Mean score of tenderness was 1.27 before treatment which was reduced to 0.20 after treatment and 0.00 after last follow up with $100 \%$ improvement. There was complete remission seen in 3 patients $(20 \%)$, marked in 6 patients (40\%), moderate improvement in 6 patients (40\%) Tamra Shalaka group mean score of pain was 2.00 before treatment which was reduced to 0.93 after treatment and 0.20 after last follow up with 90\% improvement. Mean score of tenderness was 1.33 before treatment which was reduced to 0.40 after treatment and 0.13 after last follow up with $90.2 \%$ improvement. Results in both groups was statistically highly significant with $\mathrm{p}$ value was $\leq 0.0001$ and complete remission was seen in 2 patients (13.33\%), marked 4 patients $(26.66 \%)$ and moderate improvement 9 patients (60\%). There was no patient noted with mild improvement and unchanged result in both groups. This study showed Agnikarma with Rajata Shalaka was better effective than Tamra Shalaka in relieving the pain, tenderness and other sign and symptoms of Janu Sandhigata Vata (knee joint osteoarthritis).[7]

Dr. A. Jayashree Prasad has conducted RCT as PG dissertation on Agnikarma along with Yogaraja Guggulu Vati as internal medicine in Manyastambh i.e., cervical spondylosis. In this study total 40 patients equally divided in to 2 groups. Group-A Agnikarma done with Panchaloha Shalaka in single sitting. $2^{\text {nd }}$ sitting was done on $8^{\text {th }}$ day when pain was not reduced there was no change in goniometer reading. Observation was made as before treatment, on $7^{\text {th }}, 15^{\text {th }}$ and $21^{\text {st }}$ day and follow up was done once in a month for the duration of 3 months (90 days). In Agnikarma group it was observed that pain was 2.05 before treatment it reduced to 0.60 at end of treatment which was same in group $B$, also reduces other symptoms like tenderness, stiffness etc with $\mathrm{p}$ value is less than $\leq 0.0001$ which was highly significant. At the end of treatment result shown in Agnikarma group was 10 (50\%) had good response, 7 (35\%) moderate and 3 (15\%) poor response. In Group of Yogaraja Guggulu Vati there was good response shown in 8 (40\%), 11 (55\%) moderate and 1 (5\%) had shown no response. This study observed that efficacy of Agnikarma was found slightly superior in view of instant pain management to Yograj Gugulu as internal medicine.[8]

This was a RCT study of Agnikarma on frozen shoulder conducted by Dr. Megha Tyagi as a PG dissertation. In this study total 30 patients equally divided into two groups of Agnikarma by mixing Guda, Madhu and Ghrita and wax bath therapy on affected shoulder with 2 -3 sittings in a day daily for duration of 15 days. Assessment done on $5^{\text {th }}, 10^{\text {th }}$ and $15^{\text {th }}$ day and follow up was taken after at end of 1 month treatment. It was observed that after $3^{\text {rd }}$ follow up result almost same in both the groups which were statistically significant. In Agnikarma group It was observed that pain was 2.2 before treatment it reduced to 0.4 at end of treatment with the $\mathrm{P}$-value $<0.01$ It also reduces other symptoms like tenderness, stiffness etc with $p$ value is less than $\leq 0.0001$ which shows that Agnikarma is significantly effective to reduce pain and local tenderness. Overall assessment shows that 1 patient had no improvement, 1 had mild, 3 had moderate, 8 had maximum improvement and 2 had completely cured in Agnikarma group. Conclusion made on this study was that Agnikarma with Guda, Madhu and Ghrita shown more effective result compared to wax bath therapy in relieving the pain tenderness and other sign and symptoms of frozen shoulder (Avabahuk).[9] 
This is RCT conducted by Dr. Nikita Ganjoo on Agnikarma in Kadara (corn). In this study total 15 patients taken and Agnikarma done with Pippali in single sitting, assessment done and follow up was taken on $7^{\text {th }}$ and $14^{\text {th }}$ days. After the $2^{\text {nd }}$ follow up on $14^{\text {th }}$ day result found as reduction in pain and tenderness were $86.50 \%$ and $93.35 \%$ improvement which was found to be statistically highly significant with $\mathrm{p}$ value is less than $\leq 0.001$. This study shows that Pippali can be used to create superficial burns only. So, the conclusion was Agnikarma with Pippali is effective for treating superficial Kadar lesions and cosmetically better. It can also be performed in superficial hyperkeratosis over the elbows, lateral aspect of ankle, foot and hand.[10]

Dr.Vyasdeva Mahanta conducted study on Agnikarma in cervical spondylosis. Total 33 patients selected for trial and divided into two groups. Out of them 21 completed the treatment in both groups. 11 patients treated by Agnikarma with Panchadhatu Shalaka and 10 patients treated by Trayodashanga Guggulu internally for duration of 1 month. Total 4 sittings of Agnikarma were done with follow up at interval of every $7^{\text {th }}$ day. Results are shown as improvement in reducing sign and symptoms of cervical spondylosis. In Agnikarma group, 18\% patient completely cured without recurrence, $18 \%$ had marked improvement and 63\% got improved and in Trayodasanga Guggulu group 10\% patients were cured, $30.00 \%$ had marked improvement and $60 \%$ got improved. The conclusion was that Agnikarma therapy is more effective for instant relief from pain and other symptoms in cervical spondylosis. [11]

Another study conducted by Dr. Yogesh Badwe on Agnikarma and injection therapy in Vatakantaka (Plantar fasciitis). In this trial total 60 patients studied, which is equally divided into two groups. Agnikarma done with Tamra Shalaka in group-A and in group-B Intralesional Steroid injection of Triamcinolone $40 \mathrm{mg}$ given deep into the Plantar Fascia. Follow up done on $1^{\text {st }}, 3^{\text {rd }}$ and $7^{\text {th }}$ day and assessment done after the treatment. After statistical analysis it was observed that there was significant reduction in Pain and tenderness in both groups with P-value of the two groups which is less than 0.05 so, both the treatment are equally effective. But in Agnikarma group pain and tenderness was immediately reduced when compared with injection therapy group. So, it concluded that Agnikarma is effective as treatment of Vatakantaka with advantage as immediate pain and tenderness reliever and It is cost effectiveness, easy and OPD level procedure.[12]

Dr.Vinod kumar K. Bhorale conducted RCT on Agnikarma in Greeva Sandhigata Vata (Cervical spondylosis). In 40 patients Agnikarma performed by Panchadhatu Shalaka in 3 settings at interval of every $7^{\text {th }}$ day for duration of 3 weeks along with oral Ayurvedic medication. Follow up taken on every $7^{\text {th }}$ day for 21 days after treatment and assessment was done. Total duration of study was 42 days including follow up. After the treatment and follow up it was observed that the mean score of pain and tenderness was 2.05 and 0.57 before treatment which was reduced to 0.62 and 0.25 after treatment with $69.26 \%$ and $56.5 \%$ improvement which is highly significant $(\mathrm{P}<0.01)$ almost in all parameters. The study showed that Agnikarma can be used to management chronic degenerative disorders like cervical spondylosis. It is highly effective, affordable an easy-to-handle therapy.[13]

This RCT on Agnikarma in knee joint osteoarthritis was conducted by Dr. Anju Lata and others. Total 60 patients divide in two groups of conductive and direct method of Agnikarma with Tamra Shalaka on average temperature of $150^{\circ} \mathrm{C}$ and $50-60^{\circ} \mathrm{C}$ respectively. Assessment was done as before and after treatment. It was found that the pain, tenderness and swelling was significantly reduced after treatment in both methods with P-value is less than 0.05. But in direct method more effective and satisfactory result than conductive method may be due to high temperature about $150^{\circ} \mathrm{C}$. Conclusion was Agnikarma showed good results in pain relieving when temperature of Shalaka is $150^{\circ} \mathrm{C}$ and more in conditions like osteoarthritis.[14]

This trial conducted by Dr. Vikrant Singh on Agnikarma at different temperature with injection therapy in Vatakantaka (Calcaneal spur). Total 45 patients divided in two groups. Group A: in 30 patients, Agnikarma done by specially designed instrument with average temperature at $100^{\circ} \mathrm{C}$ to $150^{\circ} \mathrm{C}$ in 13 patients and $150^{\circ} \mathrm{C}$ to $200^{\circ} \mathrm{C}$ in 17 patients. Group B: 15 patients treated with injection triamcinolone acetonide $40 \mathrm{mg}$ diluted with $2 \%$ xylocaine (2cc) intralesional at the site of maximum tenderness on heel. Follow up taken on $7^{\text {th }}$ day after treatment and it was observed that PValues for trial group (temp 100-150) is greater than 0.05 hence the effect observed is not significant, while $\mathrm{P}$-Values for remaining two groups are less than 0.05 hence it was found significant. It shows that Agnikarma which is done at $150-200^{\circ} \mathrm{C}$ got relief in pain $(76 \%)$ and tenderness (75\%) which was more than 100$150^{\circ} \mathrm{C}$. In injection Group pain and tenderness was reduced upto $82.6 \%$ and $82.4 \%$. The conclusion was that Hence Agnikarma at higher temperatures is having instant pain relief properties which is helpful in painful conditions like Vatakantaka and other musculoskeletal disorders.[15]

A case study was done by Dr Manorama on Agnikarma in 38-year female patient of chronic plantar fasciitis having pain and tenderness over right heel. Agnikarma was done with Panchdhatu Shalaka in 3 
sittings at interval of 7 day along with internally Rasna Saptak Kwath 10grams thrice a day. $1^{\text {st }}$ follow up was taken on $7^{\text {th }}$ day after $3^{\text {rd }}$ sitting. It was found that pain, tenderness and stiffness was reduced significantly and after $2^{\text {nd }}$ follow up (after 20 day) there was no recurrence of the above features noted. It shows that Agnikarma is safe, effective, economic and an easy procedure for the management of painful condition like plantar fasciitis.[16]

Another case study was by Dr. Rimpy Sharma on Agnikarma in calcaneal spur. A 42-year male patient with pain and tenderness at bilateral heels was considered. Two settings of Agnikarma done at interval of 15 days with Panchaloha Shalaka in Bindu shaped. Follow up assessment was carried out on every $7^{\text {th }}$ day after treatment $\left(7^{\text {th }}, 15^{\text {th }}, 21^{\text {st }}\right.$ and $30^{\text {th }}$ day). After last follow up It was observed that pain and tenderness reduced and patient walked without any difficulty. Wound completely healed and scar disappeared within 15 days without any complication. Conclusion was, Agnikarma is simple, cheap, safe, effective and alternative for pain management in calcaneal spur without any complications.[17]

Dr.Vyasadeva Mahanta published single patient case study of 38 years old female of tennis elbow managed by Agnikarma along with oral medication Ashwagandha powder and Navjivan Ras. Agnikarmra done in 3 settings by Panchadhatu Shalaka with shape of small multiple dots (Vilekha Dahan Vishesha) on every $7^{\text {th }}$ day for 21 days and follow was taken up to 1 month. Result shown that the relief from pain, stiffness and increased the strength of gripping power in affected hand. Burn wounds healed within 5-7 days the scars disappeared within 3-4 weeks without any untoward effect. Study showed that, this type of combination therapy provides considerable relief in pain and restricted movement of the elbow joint and also effective against other musculoskeletal disorder.[18]

Dr.Archana Maan conducted pilot study on Agnikarma in Avabahuk (frozen shoulder) along with physiotherapy. In 15 patients Agnikarma (Binduvat) done by Gud with specially designed instrument in single seating on affected shoulder joint. Follow up taken on $0^{\text {th }}, 3^{\text {rd }}, 5^{\text {th }}, 7^{\text {th }}$ and $15^{\text {th }}$ day and assessment done. Pain and tenderness immediately relieved which is $70 \%$, it shows the efficacy of Agnikarma on frozen shoulder specially for instant pain relief without any side effect and material i.e., Gud is cost effective and easily available equipment.[19]

Dr.Suresh and Dr.Yogesh Badwe conducted the review study on Agnikarma in which detail description of about Agnikarma its indication, contraindication given and some research papers were reviewed which showed Agnikarma is helpful in Agnikarma Sadhya Vyadhi a mentioned in Samhitas and it has good pain reliving effect in management of diseases like plantar fasciitis, frozen shoulder osteoarthritis and other musculoskeletal disorders. ${ }^{[20]}$

\section{DISCUSSION}

Total 15 researchers studied in this review article, out of this 11 were RCTs including 4 PG dissertations, 3 case studies, 1 review article which was published in various journals. In above studies different types of metal and non-metal materials i.e., Dahanopkarana used for Agnikarma procedure, Shalakas (metal rod) like Suvarna Shalaka (gold rod), Rajat Shalaka (silver rod), and Tamra Shalaka (copper rod), lauha Shalaka (iron rod) and Panchadhatu Shalakha (rod made of five types of metal). Non-metal materials like Pippali (Piper Longum), Ajashakrut (goat excretact), Kshaudra (honey), Guda (jaggery) and Sneha are used in various painful disorders. Agnikarma were done in Multiple sittings in different articles which was completely depends on remission of mainly pain in various disorders, still 2 to 3 sittings were performed in various studies. Some papers show that heat energy is important to relieve the pain. Metal Salakas seen more potent because of heat retention and transmission capacity is more than $150^{\circ} \mathrm{C}$ temperature and it can burn epidermis layer (Twakadagdha) which is important in Agnikarma. Nonmetals material like Pippali found less effective because of its low temperature retention capacity and it burns only superficial layer of skin. Different Shalaka were use in various musculoskeletal disorders but result was statistically same in different articles. Sushruta has described Agnikarma in effective when there is Atyugraruja (intense pain) in Snayu-SandhiAshti i.e., musculoskeletal disorders.[21] Agnikarma was useful for immediate pain relief and same was observed in above different research papers.

\section{Probable Mode of Action of Agnikarma}

Agnikarma act on a multi-factorial level in the body and its importance lies in its action. Exact mechanism action of Agnikarma still remains unsolved. Some theories can be adopted to explain these mechanisms but their action varies according to the condition.

According to Ayurveda it acts against Vata and Kapha Dosha by its Ushna (hot), Tikshna (penetrating), Sukshma (minute), Laghu (small), Vyavayi (quick acting), and Vikasi (quickly spreading) Guna and it breaks Srotoavarodha, produced due to Vata and Kapha, results in relieving pain and inflammation at that site.[22]

The heat therapy, which is given at the local or affected area, increases the local blood circulation by vasodilatation, local metabolic process speedup, waste products get excreted, reduce edema, accelerate repair, and the which resulting in decreased intensity of pain.[23] 
Agnikarma may stimulates the sensory receptor lying in the muscle, by sending a message to the brain which stimulates the pituitary gland to release endorphin which in turn binds with opiate receptors in the pain cells to block the pain stimuli. Endorphin is a naturally occurring neuro peptide and like morphine and other opiates it has a marked propensity for binding on to the "opiate receptors" of the pain cell in the brain.[24]

The pain receptors in the skin and other tissues are all having free nerve endings, due to hot Shalaka there is destruction of the free nerve endings and it causes, closing the "gate" and prevent the sensory transmission of pain.[25]

\section{CONCLUSION}

From this review, it can be concluded that Agnikarma procedure can be done by using different materials and different temperature according to various painful conditions to mostly to relieve the pain immediately. It is a potent and minimally invasive Para-surgical procedure. Most of study conducted on musculoskeletal disorders like cervical spondylosis, osteoarthritis of knee joint, painful heel like plantar fasciitis, calcaneal spur, tennis elbow, sciatica, frozen shoulder, corn etc. from this review can be concluded that Agnikarma with different kind of Shalakas is found significantly effective in pain management in musculoskeletal disorders in almost all the studies. It can be performed combination with other supportive oral medications. It is simple, effective, convenient and economic for the patient with no or minimal complication. More scientific and Molecular studies are required to know the exact action and its applicability on the large scale.

\section{REFERENCES}

1. Dr.Kaviraj Ambikadutt Shastri, Ayurveda tatva sandipika hindi commentary, Shushrut Samhita of Shushruta Purvardha, Sutra sthana 12/9-10; Varanasi; Chaukhamba Sanskrit Sansthan; 2016, Page 52.

2. Dr.Kaviraj Ambikadutt Shastri, Ayurveda tatva sandipika hindi commentary, Shushrut Samhita of Shushruta Purvardha, Sutra sthana 12/3; Varanasi; Chaukhamba Sanskrit Sansthan; 2016, Page 50.

3. Harishchandra VKS. Chikitsa sthan 28/56. In: Charak Samhita, Part 2. Varanasi, India: Chaukhambha Orentalia; 2012. page 720.

4. Dr.Kaviraj Ambikadutt Shastri, Ayurveda tatva sandipika hindi commentary, Shushrut Samhita of Shushruta Purvardha, Sutra sthana 12/4; Varanasi; Chaukhamba Sanskrit Sansthan; 2016, Page 51.

5. Dr.Kaviraj Ambikadutt Shastri, Ayurveda tatva sandipika hindi commentary, Shushrut Samhita of Shushruta Purvardha, Sutra sthana 12/11;
Varanasi; Chaukhamba Sanskrit Sansthan; 2016, Page 52.

6. Dr Shrikant Patel. A comparative study on efficacy of Agnikarma with Pippali and Shalaka in Gridhrasi; Dissertation of RGUHS; 2011.

7. Dr. Sucheta ray, A comparative study on efficacy of Agnikarma by Rajat and Tamra shalaka in sandhigata vata which special reference to janu sandhi; Dissertation of RGUHS; 2012.

8. Dr. A. jayshree Prasad. Efficacy of Agnikarma in the management of manyastambha- a clinical studyDissertation of RGUHS; 2011.

9. Dr.Megha Tyagi. Pilot study of Agnikarma on frozen shoulder -Avabahuk; Dissertation of RGUHS; 2011.

10. Nikita Ganjoo. Role of Agnikarma with Pippali on Kadara- An open labeled clinical trial. AYU (An International Quarterly Journal of Research in Ayurveda); 2017: 38(1-2): 52-56.

11. Dr. Mahanta VD, Dudhamal TS, Gupta SK. Clinical Efficacy of Agnikarma in the Management of Sandhigata Vata w.s.r. to Cervical Spondylosis. Indian Journal of Ancient Medicine and Yoga 2012; 5(1):5-12.

12. Dr. Yogesh Badwe, Dr Bharat $R$, Dr Amit P. Comparative study of Agnikarma and intralesional steroidal injection in Vatakantaka w.s.r.Plantar fasciitis, IJSR: 2019; 8 (10); 39-40.

13. Dr. Vinod Kumar K. Bhorale, Dr.M. R. Hungundi. A Clinical Evaluation of Agnikarma in the management of Greeva Sandhigata Vata w.s.r. to Cervical Spondylosis. JAIM Sci 2019; 4: 65-70.

14. Dr Lata A, Badwe Y, Vaidya U. A comparative study of conductive and direct method of Agnikarma with Tamra Shalaka in Sandhigatvata with special reference to osteoarthritis of knee joint. IJAPR; 2015; 3: 37-40.

15. Dr. Vikrant Singh, Dr. Umesh V, Dr. Nischay B. Effect of Agnikarma (thermal cautery) at different temperatures in Vatkantaka wsr to calcaneal spur, IERJ;2016; 2(1 2); 52-53.

16. Dr. Manorma s, Sanjeev S,Suman S, Rahul S. Effect of Agnikarma on chronic plantar fasciitis- A case report. Environment Conservation Journal; 2019; $20 ; 73-77$.

17. Dr. Rimpy sharma, dr. Sahil basotra. A case study of management of calcaneal spurs with Agnikarma. IJAR; 2019; 9(12); 21-22.

18. Dr Mahanta Vyasadeva, Dudhmal TS, Gupta SK. Management of Tennis elbow by Agnikarma. JAIM, 2013; 4(1):45-47.

19. Maan A, Umesh V, Amit P. Pilot study on effect of Agnikarma by Gud in Avabahuka. Int Ayurvedic Med J 2017; 5: 2296-9. 
20. Suresh S. Podhade, Yogesh R. Badwe, Agnikarma in Ayurveda: A Review, ADJIM 2020: 5(3), p. 17-23.

21. Dr.Kaviraj Ambikadutt Shastri, Ayurveda tatva sandipika hindi commentary, Shushrut Samhita of Shushruta Purvardha, Sutra sthana 12/20; Varanasi; Chaukhamba Sanskrit Sansthan; 2016,Page 54.

22. Dr Shekokar AV, Borkar KM. Role of Agnikarma in the management of chronic plantar fasciitis. IJAM, 2013; 4:421-5.

23. Dr. Vinodkumar K. Bhorale, Dr.M. R. Hungundi. A Clinical Evaluation of Agnikarma in the

\section{Cite this article as:}

Badwe Yogesh, Shilvant Rishabh, Shinde Jyoti. Role of Agnikarma on Pain Management of Various Musculoskeletal Disorders: A Review Study. International Journal of Ayurveda and Pharma Research. 2021;9(8):89-96.

https://doi.org/10.47070/ijapr.v9i8.2040

$$
\text { Source of support: Nil, Conflict of interest: None Declared }
$$

management of Greeva Sandhigata Vata w.s.r. to Cervical Spondylosis. JAIM Sci, 2019; 4:65-70.

24. Dr. Vinodkumar K. Bhorale, Dr.M. R. Hungundi. A Clinical Evaluation of Agnikarma in the management of Greeva Sandhigata Vata w.s.r. to Cervical Spondylosis. JAIM Sci, 2019; 4:65-70.

25. Dr. Vinod kumar K. Bhorale, Dr.M. R. Hungundi. A Clinical Evaluation of Agnikarma in the management of Greeva Sandhigata Vata w.s.r. to Cervical Spondylosis. JAIM Sci, 2019; 4:65-70.

\section{*Address for correspondence Dr. Shilvant Rishabh \\ PG Scholar, \\ Department of Shalyatantra, Shri Ayurved Mahavidyalaya, Nagpur, Maharashtra, India. \\ Email: \\ rishabhshilvant21@gmail.com}

Disclaimer: IJAPR is solely owned by Mahadev Publications - dedicated to publish quality research, while every effort has been taken to verify the accuracy of the content published in our Journal. IJAPR cannot accept any responsibility or liability for the articles content which are published. The views expressed in articles by our contributing authors are not necessarily those of IJAPR editor or editorial board members. 


\section{Agnikarma with Shalaka}

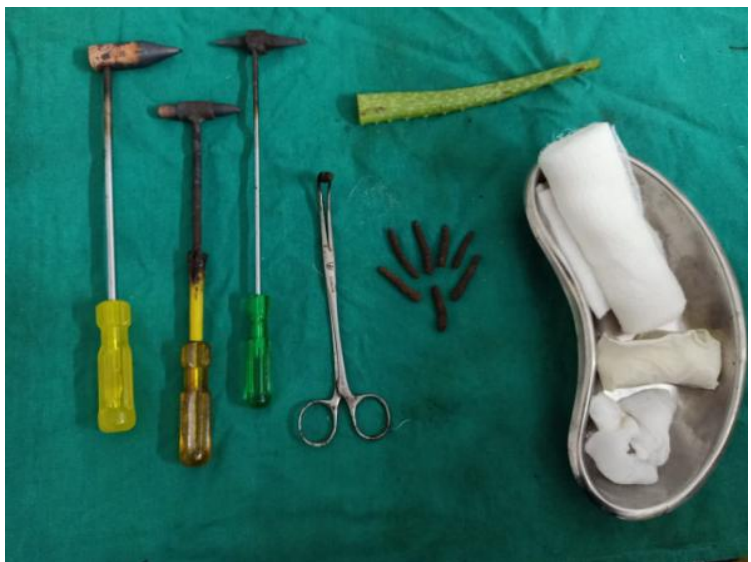

Agnikarma instruments (Dahanopkarnas)

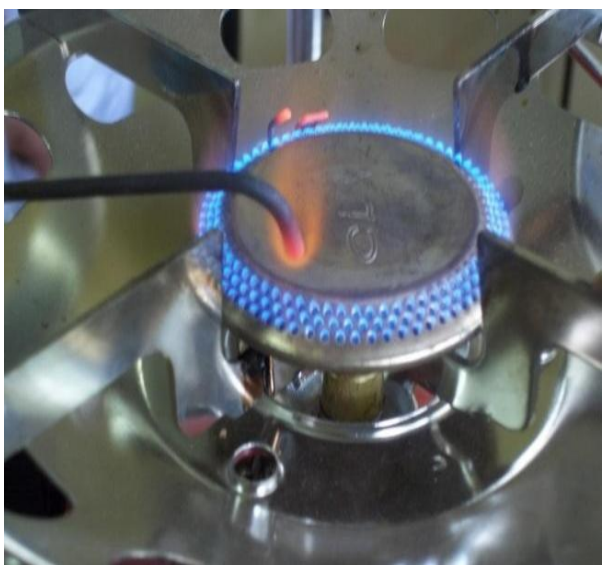

Red hot Loha shalaka
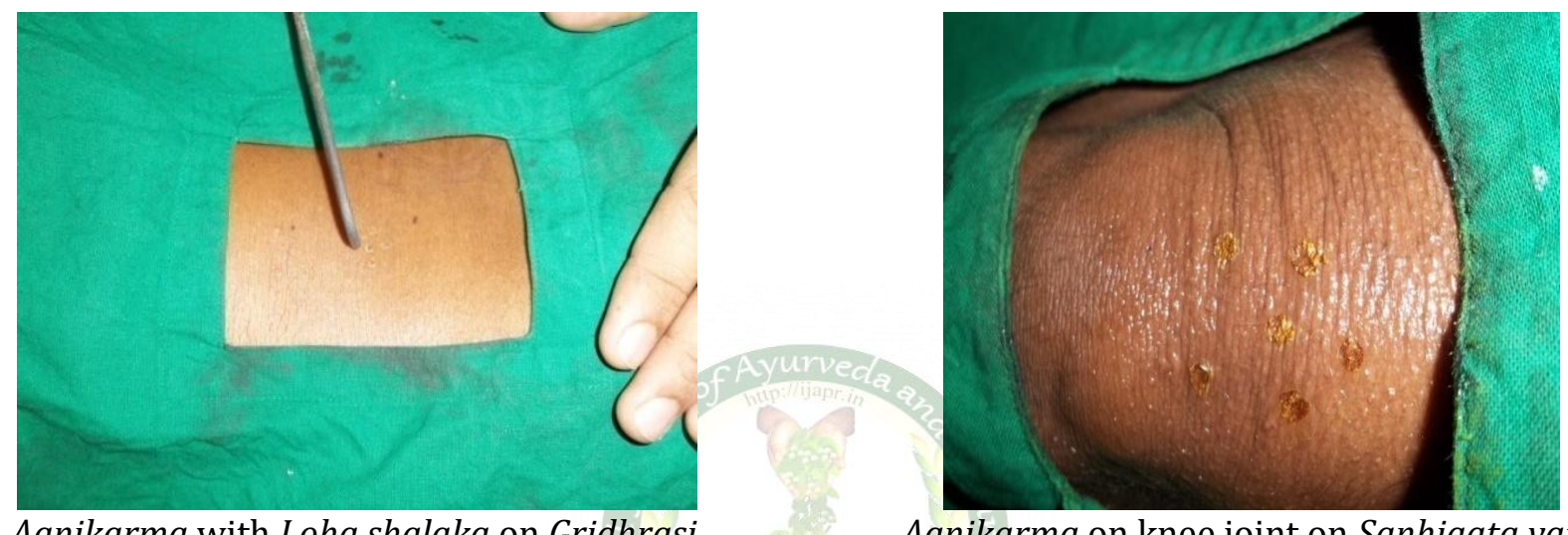

Agnikarma with Loha shalaka on Gridhrasi

Agnikarma on knee joint on Sanhigata vata

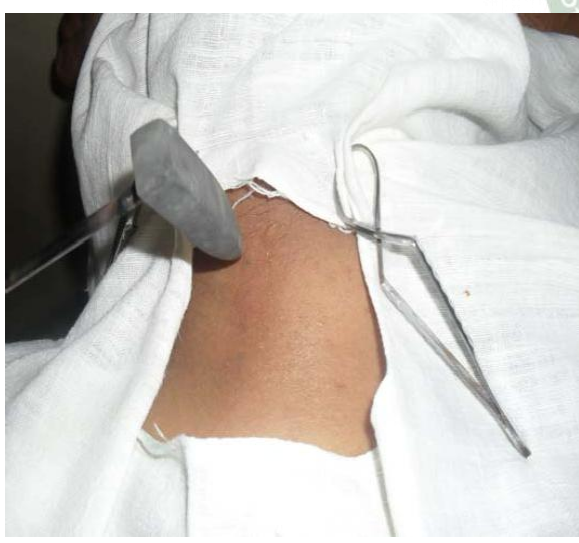

Agnikarma on Manyastambha

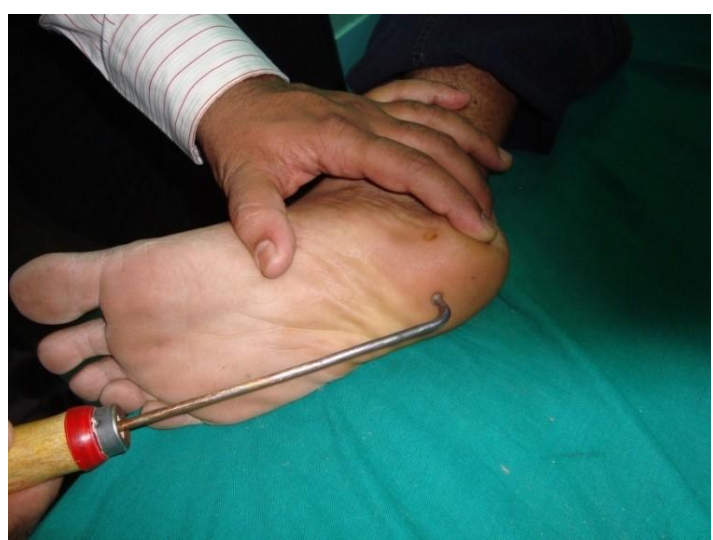

Calanium spur-Shalaka

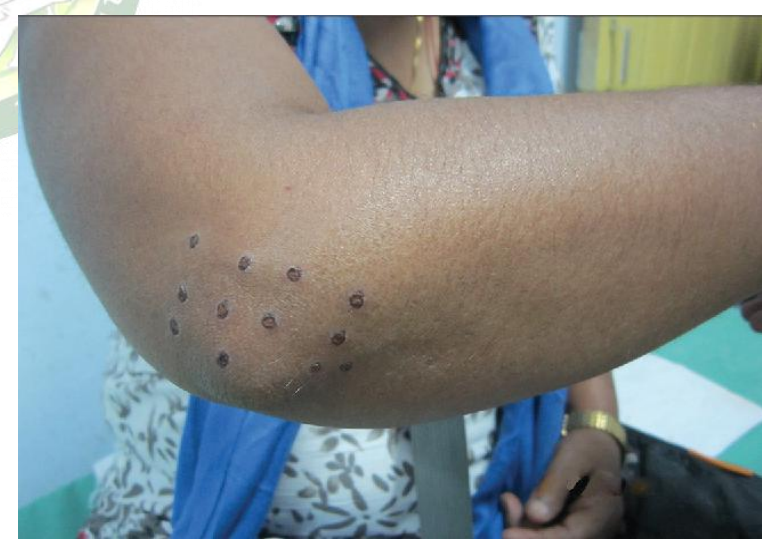

Agnikarma on tenis elbow

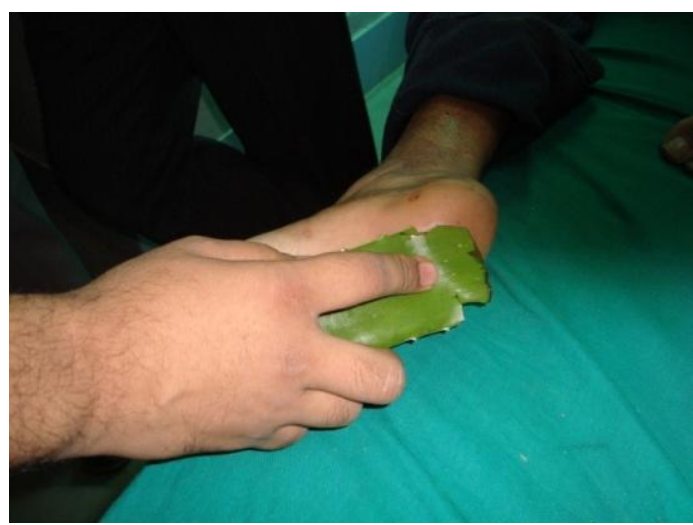

Alovera application after Agnikarma 


\section{Agnikarma with Pippali}

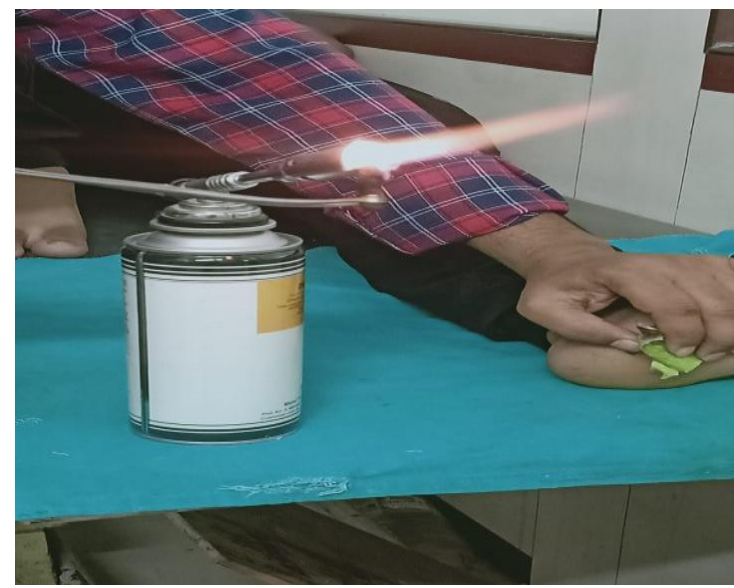

Heating Pippali on flame

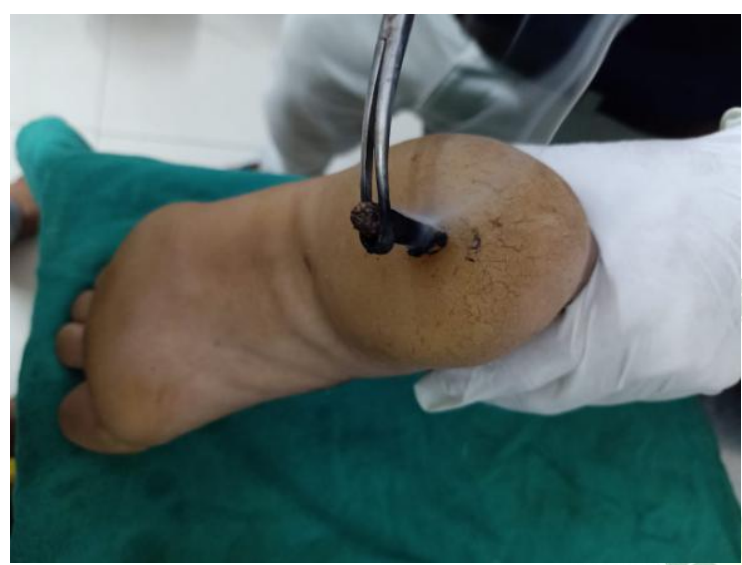

During Agnikarma with Pippali on plantar fasciitis

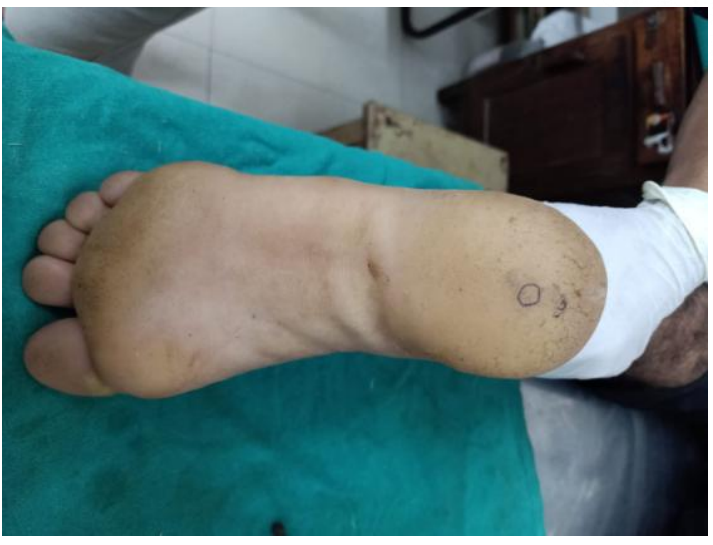

Before Agnikarma with Pippali on plantar fasciitis

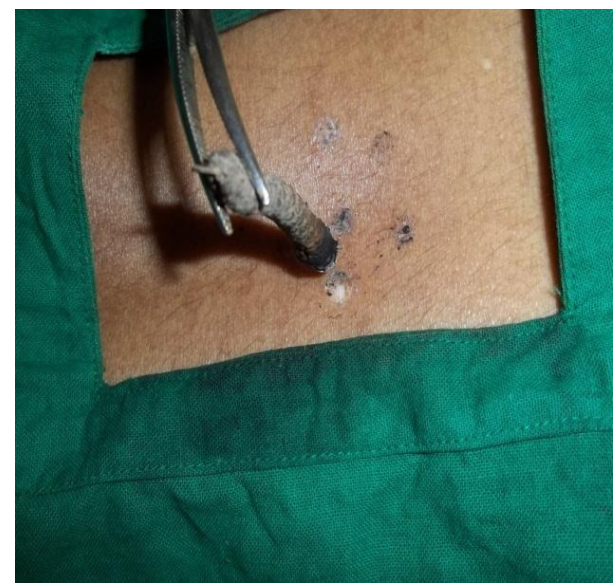

Agnikarma with Pippali on Gridhraasi

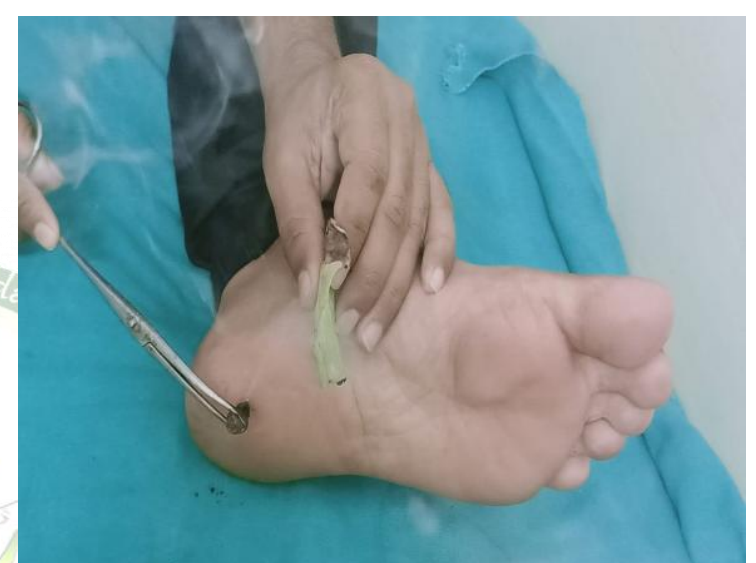

Agnikarma with Pippali with application of Alovera

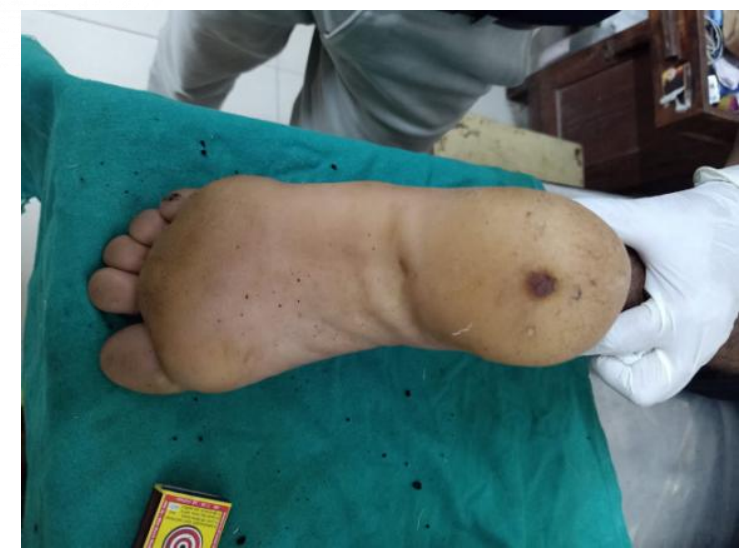

After Agnikarma with Pippali on Plantar fasciitis 